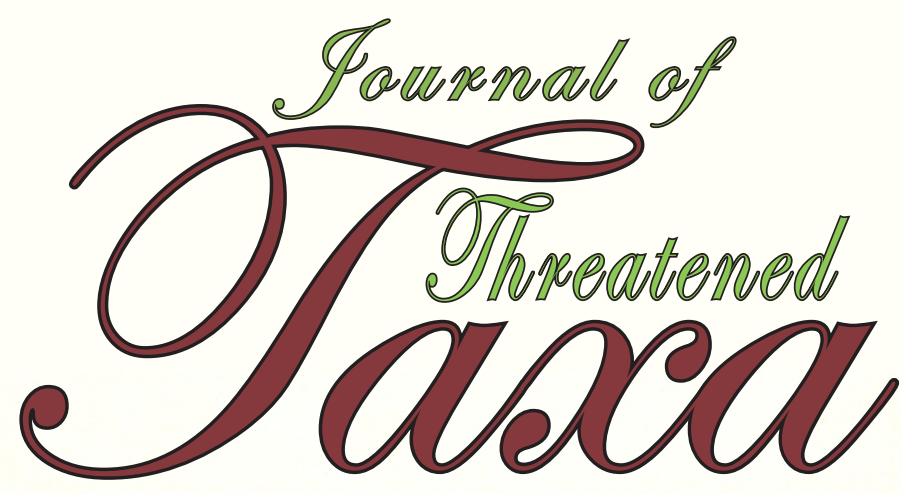

10.11609/jott.2021.13.14.20143-20310 enever.threatenedtaxa.org

26 December 2021 (Online \& Print) Val. 13 | Na. 14 | Pages: 20143-20310 155n 0974-7907 (Online) 155n 0974-7893 (Print)

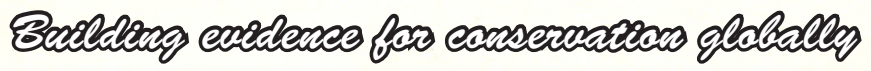

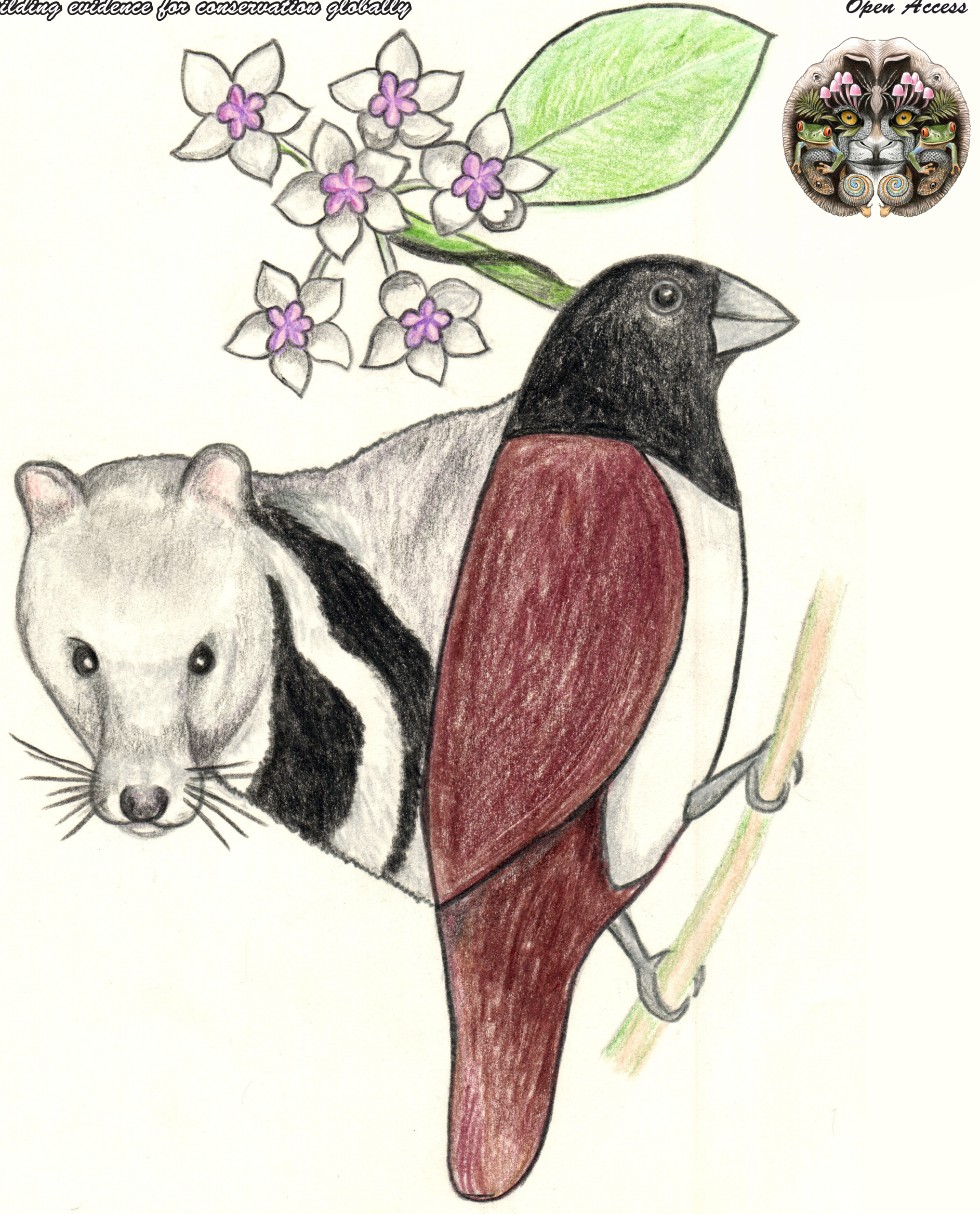

Open Access 


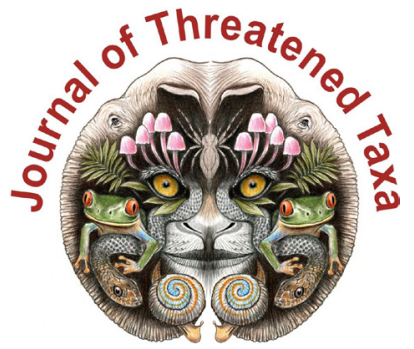

ISSN 0974-7907 (Online); ISSN $0974-7893$ (Print)

Publisher

Host

Wildlife Information Liaison Development Society

www.wild.zooreach.org

Zoo Outreach Organization www.zooreach.org

No. 12, Thiruvannamalai Nagar, Saravanampatti - Kalapatti Road, Saravanampatti, Coimbatore, Tamil Nadu 641035, India

Ph: +91 9385339863 | www.threatenedtaxa.org

Email: sanjay@threatenedtaxa.org

EDITORS

\section{Founder \& Chief Editor}

Dr. Sanjay Molur

Wildlife Information Liaison Development (WILD) Society \& Zoo Outreach Organization (ZOO),

12 Thiruvannamalai Nagar, Saravanampatti, Coimbatore, Tamil Nadu 641035, India

\section{Deputy Chief Editor}

Dr. Neelesh Dahanukar

Noida, Uttar Pradesh, India

\section{Managing Editor}

Mr. B. Ravichandran, WILD/ZOO, Coimbatore, India

\section{Associate Editors}

Dr. Mandar Paingankar, Government Science College Gadchiroli, Maharashtra 442605, India

Dr. Ulrike Streicher, Wildlife Veterinarian, Eugene, Oregon, USA

Ms. Priyanka lyer, ZOO/WILD, Coimbatore, Tamil Nadu 641035, India

Dr. BA. Daniel, $200 / \mathrm{WILD}$, Coimbatore, Tamil Nadu 641035, India

\section{Editorial Board}

Dr. Russel Mittermeie

Executive Vice Chair, Conservation International, Arlington, Virginia 22202, USA

\section{Prof. Mewa Singh Ph.D., FASc, FNA, FNASc, FNAPsy}

Ramanna Fellow and Life-Long Distinguished Professor, Biopsychology Laboratory, and Institute of Excellence, University of Mysore, Mysuru, Karnataka 570006, India; Honorary Professor, Jawaharlal Nehru Centre for Advanced Scientific Research, Bangalore; and Adjunct Professor, National Institute of Advanced Studies, Bangalore

\section{Stephen D. Nash}

Scientific Illustrator, Conservation International, Dept. of Anatomical Sciences, Health Sciences Center, T-8, Room 045, Stony Brook University, Stony Brook, NY 11794-8081, USA

\section{Dr. Fred Pluthero}

Toronto, Canada

\section{Dr. Priya Davidar}

Sigur Nature Trust, Chadapatti, Mavinhalla PO, Nilgiris, Tamil Nadu 643223, India

\section{Dr. Martin Fisher}

Senior Associate Professor, Battcock Centre for Experimental Astrophysics, Cavendish

Laboratory, JJ Thomson Avenue, Cambridge CB3 OHE, UK

\section{Dr. John Fellowes}

Honorary Assistant Professor, The Kadoorie Institute, 8/F, T.T. Tsui Building, The University of Hong Kong, Pokfulam Road, Hong Kong

\section{Prof. Dr. Mirco Solé}

Universidade Estadual de Santa Cruz, Departamento de Ciências Biológicas, Vice-coordenado do Programa de Pós-Graduação em Zoologia, Rodovia Ilhéus/Itabuna, Km 16 (45662-000)

Salobrinho, Ilhéus - Bahia - Brasil

\section{Dr. Rajeev Raghavan}

Professor of Taxonomy, Kerala University of Fisheries \& Ocean Studies, Kochi, Kerala, India

\section{English Editors}

Mrs. Mira Bhojwani, Pune, India

Dr. Fred Pluthero, Toronto, Canad

Mr. P. Ilangovan, Chennai, India

Web Development

Mrs. Latha G. Ravikumar, ZOO/WILD, Coimbatore, India

\section{Typesetting}

Mr. Arul Jagadish, ZOO, Coimbatore, India

Mrs. Radhika, ZOO, Coimbatore, India

Mrs. Geetha, ZOO, Coimbatore India
Fundraising/Communications

Mrs. Payal B. Molur, Coimbatore, India

Subject Editors 2018-2020

Fungi

Dr. B. Shivaraju, Bengaluru, Karnataka, India

Dr. R.K. Verma, Tropical Forest Research Institute, Jabalpur, India

Dr. Vatsavaya S. Raju, Kakatiay University, Warangal, Andhra Pradesh, India

Dr. M. Krishnappa, Jnana Sahyadri, Kuvempu University, Shimoga, Karnataka, India

Dr. K.R. Sridhar, Mangalore University, Mangalagangotri, Mangalore, Karnataka, India

Dr. Gunjan Biswas, Vidyasagar University, Midnapore, West Bengal, India

\section{Plants}

Dr. G.P. Sinha, Botanical Survey of India, Allahabad, India

Dr. N.P. Balakrishnan, Ret. Joint Director, BSI, Coimbatore, India

Dr. Shonil Bhagwat, Open University and University of Oxford, UK

Prof. D.J. Bhat, Retd. Professor, Goa University, Goa, India

Dr. Ferdinando Boero, Università del Salento, Lecce, Italy

Dr. Dale R. Calder, Royal Ontaro Museum, Toronto, Ontario, Canada

Dr. Cleofas Cervancia, Univ. of Philippines Los Baños College Laguna, Philippines

Dr. F.B. Vincent Florens, University of Mauritius, Mauritius

Dr. Merlin Franco, Curtin University, Malaysia

Dr. V. Irudayaraj, St. Xavier's College, Palayamkottai, Tamil Nadu, India

Dr. B.S. Kholia, Botanical Survey of India, Gangtok, Sikkim, India

Dr. Pankaj Kumar, Kadoorie Farm and Botanic Garden Corporation, Hong Kong S.A.R., China

Dr. V. Sampath Kumar, Botanical Survey of India, Howrah, West Bengal, India

Dr. A.J. Solomon Raju, Andhra University, Visakhapatnam, India

Dr. Vijayasankar Raman, University of Mississippi, USA

Dr. B. Ravi Prasad Rao, Sri Krishnadevaraya University, Anantpur, India

Dr. K. Ravikumar, FRLHT, Bengaluru, Karnataka, India

Dr. Aparna Watve, Pune, Maharashtra, India

Dr. Qiang Liu, Xishuangbanna Tropical Botanical Garden, Yunnan, China

Dr. Noor Azhar Mohamed Shazili, Universiti Malaysia Terengganu, Kuala Terengganu, Malaysia

Dr. M.K. Vasudeva Rao, Shiv Ranjani Housing Society, Pune, Maharashtra, India

Prof. A.J. Solomon Raju, Andhra University, Visakhapatnam, India

Dr. Mandar Datar, Agharkar Research Institute, Pune, Maharashtra, India

Dr. M.K. Janarthanam, Goa University, Goa, India

Dr. K. Karthigeyan, Botanical Survey of India, India

Dr. Errol Vela, University of Montpellier, Montpellier, France

Dr. P. Lakshminarasimhan, Botanical Survey of India, Howrah, India

Dr. Larry R. Noblick, Montgomery Botanical Center, Miami, USA

Dr. K. Haridasan, Pallavur, Palakkad District, Kerala, India

Dr. Analinda Manila-Fajard, University of the Philippines Los Banos, Laguna, Philippines

Dr. P.A. Sinu, Central University of Kerala, Kasaragod, Kerala, India

Dr. Afroz Alam, Banasthali Vidyapith (accredited A grade by NAAC), Rajasthan, India

Dr. K.P. Rajesh, Zamorin's Guruvayurappan College, GA College PO, Kozhikode, Kerala, India

Dr. David E. Boufford, Harvard University Herbaria, Cambridge, MA 02138-2020, USA

Dr. Ritesh Kumar Choudhary, Agharkar Research Institute, Pune, Maharashtra, India

Dr. Navendu Page, Wildlife Institute of India, Chandrabani, Dehradun, Uttarakhand, India

\section{Invertebrates}

Dr. R.K. Avasthi, Rohtak University, Haryana, India

Dr. D.B. Bastawade, Maharashtra, India

Dr. Partha Pratim Bhattacharjee, Tripura University, Suryamaninagar, India

Dr. Kailash Chandra, Zoological Survey of India, Jabalpur, Madhya Pradesh, India

Dr. Ansie Dippenaar-Schoeman, University of Pretoria, Queenswood, South Africa

Dr. Rory Dow, National Museum of natural History Naturalis, The Netherlands

Dr. Brian Fisher, California Academy of Sciences, USA

Dr. Richard Gallon, llandudno, North Wales, LL30 1UP

Dr. Hemant V. Ghate, Modern College, Pune, India

Dr. M. Monwar Hossain, Jahangirnagar University, Dhaka, Bangladesh

Mr. Jatishwor Singh Irungbam, Biology Centre CAS, Branišovská, Czech Republic.

Dr. Ian J. Kitching, Natural History Museum, Cromwell Road, UK

Dr. George Mathew, Kerala Forest Research Institute, Peechi, India

For Focus, Scope, Aims, and Policies, visit https://threatenedtaxa.org/index.php/JoTT/aims_scope
For Article Submission Guidelines, visit https://threatenedtaxa.org/index.php/JoTT/about/submissions
For Policies against Scientific Misconduct, visit https://threatenedtaxa.org/index.php/JoTT/policies_various 


\title{
New distribution record of a true coral species, Psammocora contigua (Esper, 1794) from Gulf of Kachchh Marine National Park \& Sanctuary, India
}

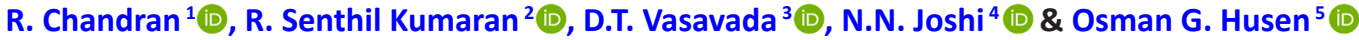 \\ ${ }^{1-4}$ Marine National Park \& Sanctuary, Forest Colony, Jamnagar, Gujarat 361001, India. \\ ${ }^{5}$ Sikka-Range Forest office, MNP\&S, Gakat Naka, Sikka, Gujarat 361141, India. \\ ${ }^{1}$ chandranrethnaraj@gmail.com (corresponding author), ${ }^{2}$ senthil.ifs@gmail.com, ${ }^{3}$ dtvasavada@yahoo.com, ${ }^{4}$ rfojoshi@yahoo.com, \\ ${ }^{5}$ husengadh4796@gmail.com
}

\begin{abstract}
Reef-building corals are generally confined to tropical waters across the world oceans. But some coral species are able to tolerate even inhospitable environments and suboptimal extremes, and form lower diversity reefs habitats such as the Gulf of Kachchh, located along the northwestern coast of India. Among the reported hard coral species so far from the Gulf of Kachchh, genus Psammocora is represented by only one species, $P$. digitata. The present study confirmed a new distribution record of Psammocora contigua from Narara Island. Due to the changing hydro-geographic conditions in the Kachchh region, ramose and branching coral species have been believed to be extinct completely, leaving no sign of live colonies. $P$. contigua, recorded during the present study is the only living species with ramose growth form recorded so far from the Kachchh waters. The present study also holds out hope to record more new coral species records from the region.
\end{abstract}

Keywords: New coral distribution, Gulf of Kachchh, Narara, Psammocora, marginalized reef.

Contributing much in designing, building, and maintaining coral reef habitats in the marine realms, scleractinian corals are often considered as 'ecosystem engineers'. Although these corals are widely distributed throughout the world's seas and deeper ocean environments, reef-building coral species are particularly live in shallow tropical and subtropical seas only. The distribution of corals in the world's oceans generally is confined in two distinct regions; the wider Caribbean (Atlantic Ocean) and the Indo-Pacific (from eastern Africa and the Red Sea to the Central Pacific Ocean) (Veron 1995). As updated by Hoeksema \& Cairns (2019), a total of 1,625 coral species have been reported from the seas around the world. Among them, at least 900 extant hermatypic scleractinian species (Wallace 1999; Veron 2000) and at least 707 ahermatypic species (Cairns 1999; Tenjing et al. 2019) are recorded. The diversity of coral species is far greater in the Indo-Pacific than in the Atlantic region; the Atlantic amount to only $1 / 20^{\text {th }}$ of the number to be found in the Indo-Pacific waters (Veron 1995; Spalding et al. 2001). In most parts of the world, the species richness of coral reefs increases towards the equator, particularly the 'Coral Triangle' region, the 'epicentre' of the richest coral biodiversity (Veron et al. 2015). From this epicenter, the species richness of corals decreases towards latitudes and eastern and western realms. It is astounding to note that not a single coral species is common to both of the Indo-Pacific and the

Citation: Chandran, R., R.S. Kumaran, D.T. Vasavadu, N.N. Joshi \& O.G. Husen (2021). New distribution record of a true coral species, Psammocora contigua (Esper, 1794) from Gulf of Kachchh Marine National Park \& Sanctuary, India. Journal of Threatened Taxa 13(14): 20266-20271. https://doi.org/10.11609/jott.6851.13.14. 20266-20271

Copyright: (c) Chandran et al. 2021. Creative Commons Attribution 4.0 International License. JoTT allows unrestricted use, reproduction, and distribution of this article in any medium by providing adequate credit to the author(s) and the source of publication.

Funding: Marine National Park \& Sanctuary, Jamnagar.

Competing interests: The authors declare no competing interests.

Acknowledgements: The authors are grateful to the Gujarat Forest Department and Gujarat Marine National Park Conservation Society for the facilities extended to carry out this research. The authors are also thankful to Shri. Pratik Joshi, Range Forest Officer-Marine National Park-Jamnagar for supporting in the manuscript preparation. 
Atlantic Ocean regions of the world (Veron et al. 2015). Reef-building corals prefer to grow best in shallow, clear waters that are poor in nutrients, annual water temperature ranges from $23^{\circ} \mathrm{C}$ to $29^{\circ} \mathrm{C}$ and a stable salinity range of 27-38 ppt (Achituv \& Dubinsky 1990). Because of these strict environmental restrictions, reef-building corals are generally confined to tropical waters. But some coral species are able to tolerate inhospitable environments, sub-optimal extremes and form lower diversity reefs habitats. To a limited extent, corals of those environments can adapt to ambient conditions; consequently, the upper lethal temperature for a species in the tropics will be higher than that of the same species in the subtropics (Camp et al. 2018). Marginalized reefs distribution in the Gulf of Kachchh, along the northwestern coast of India includes sturdy reef assemblages that are adapted to thrive in extreme environmental conditions.

Coral reefs of the Kachchh are scanty and less diverse when compared with other major coral reef regions of India. The meagerness is explained due to the transgression of the sea levels of the Late PleistoceneHolocene period and the upliftment of tectonic plates of the Gulf (Srivastava 1965). In addition, the prevailing arid climate and the semi-diurnal tidal amplitude fluctuations imply in water quality and heavy sediment depositions on coral reefs hamper their recovery to a healthy state (Michael et al. 2009). Residual coral species living today are quite distinctive in terms of their isolation and their high degree of adaptation to survive in such extreme oceanographic and climatic conditions (Dixit et al. 2010). The water in the Kachchh is murky almost throughout the year and possibilities for exploring sub-tidal reefs is only hardly possible. The distribution of corals in the Gulf is restricted mostly to fore-reefs, edges of reef flats along with the low-tide marks and, inter-tidal pools to reef flats for some extend. So, most studies on coral species diversity and distribution in the Gulf carried out so far were from the low-tide exposed reefs only. A total of 63 hard coral species belonging to 28 genera, under 11 families have been recorded so far from the Gulf of Kachchh (Satyanarayana et al. 2018). Among them, the genus Psammocora is represented by only one species, P. digitata. Psammocora (Dana, 1846) is an Indo-Pacific coral genus, presently comprised of 11 nominal species in the monotypic family Psammocoridae (WoRMS 2020). Species of this genus have highly plastic branching growth forms and exhibit considerable structural complexity in skeletal features (Benzoni et al. 2007). This report confirms the first occurrence of another species of Psammocora in the Gulf of Kachchh reefs.

\section{MATERIALS AND MethodS}

Gulf of Kachchh is an East-West oriented, funnel shaped indentation along the Gujarat coast, approximately $125 \mathrm{~km}$ long and $75 \mathrm{~km}$ wide. The southern shore of the Gulf is fringed by some 42 islands and islets. Seaward side edges and low-tide marks and of these islands are predominantly inhabited by a rich coverage of coral reef. During a regular coral reef health monitoring survey in the Islands of Gulf of Kachchh Marine National Park area, the occurrence of Psammocora contigua was recorded on August 2020, a zero low-tide day from an intertidal reef flat of Narara Island $\left(22.455^{\circ} \mathrm{N} 69.671^{\circ} \mathrm{E}\right)$ (Figure 1). A recently bleached colony was collected for taxonomic identification. The collected specimen was treated with $10 \%$ sodium hypochlorite solution to remove all soft parts, after that washed in freshwater and dried for recording corallites morphology and morphometry. The largest corallites from different parts of branch surface and valleys, which were not visibly undergoing any budding process, were selected for morphometrical analysis. Likewise, average branch variables were measured from different branches of the coral colony with a vernier caliper. The specimen was identified up to species level following published original and synonymized taxonomic descriptions of Stefani et al. (2008) and Venkataraman \& Satyanarayana (2012). After taxonomical analysis, the same specimen was deposited as a voucher specimen (MNP/Coel/202001 ) at the Marine Biodiversity Museum, Marine National Park (Gujarat Forests), Jamnagar, India.

\section{RESULTS \\ Diagnosis}

Colony is sub-massive or ramous (Image 1a, 2a) but some younger colonies observed with encrusting growth forms (Image 1c). Live colony was pale brown in colour. Total diameter of the examined colony was $12.82 \mathrm{~cm}$ and height measured $6.24 \mathrm{~cm}$. Branches short, stout, tend to be flattened and often anastomosed. Branch tip acute with irregular foliose ends and also form pits at many places (Image 1c). At the base of the colony, branches form valleys. Maximum height of the branch measured up to $2.89 \mathrm{~cm}$ and the maximum height of the distal part of the branch measured $1.22 \mathrm{~cm}$. Maximum distance between distal portions of the branches measured up to $2.3 \mathrm{~cm}$. The surface of the colony is smooth.

Corallites are very small, shallow, without any prominent walls and, give a smooth surface appearance to the colony (Image $2 b, c$ ). An average number of 26 corallites per $\mathrm{cm}^{2}$ was measured. The arrangement of septa in each corallite gives a flower-like appearance. 


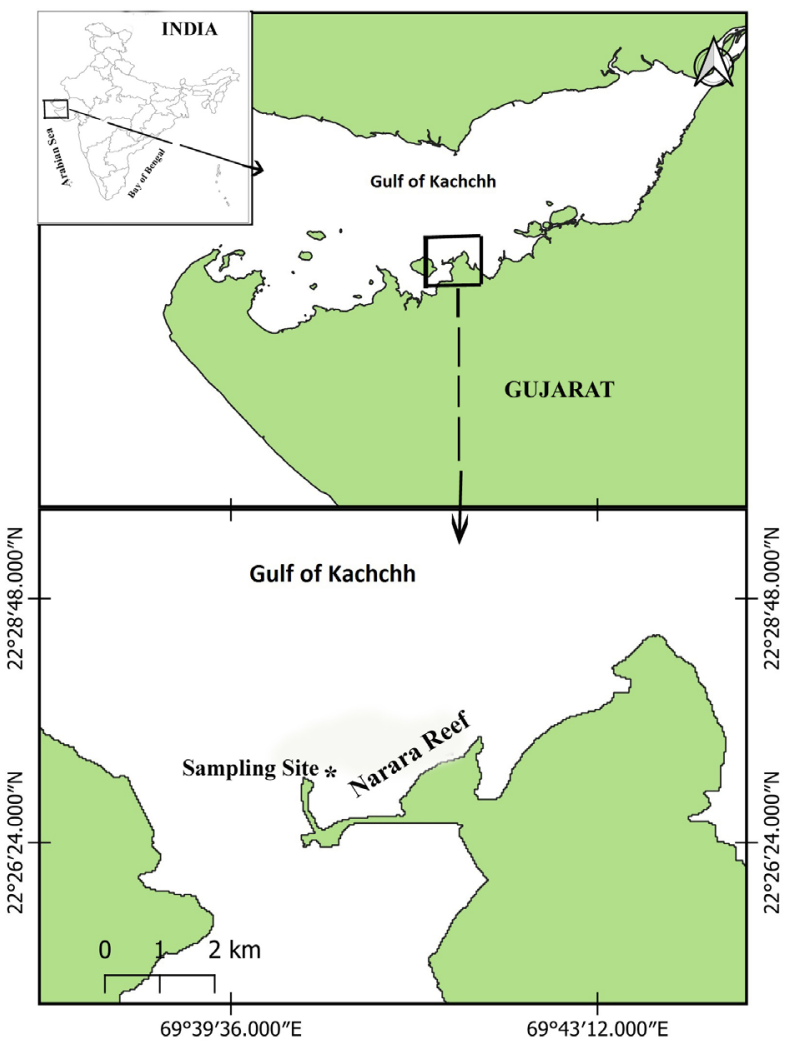

Figure 1. The location from where the coral species recorded in the Gulf of Kachchh MNP area.

Corallite walls are indistinct. Calice diameter measured up to $0.789 \mathrm{~mm}$ and fossa diameter up to $0.184 \mathrm{~mm}$. Columella was made of a group of pinnules (Image $2 \mathrm{~d}$ ) and measured maximum up to $0.131 \mathrm{~mm}$ in diameter. Septal margins with spiny process tend to arrange in whorls along their length. In most of the corallites, eight septa reach the fossa and four of them are petaloid. Maximum length of the petaloid septa reaching the fossa up to $0.302 \mathrm{~mm}$ and width up to $0.118 \mathrm{~mm}$. Nonpetaloid septa reaching the fossa measured up to 0.105 $\mathrm{mm}$ wide. Likewise, enclosed petaloid septa measured up to $0.235 \mathrm{~mm}$ wide and $0.392 \mathrm{~mm}$ long.

Series of calices often form and can be up to more than 25 calices long even in diameter and following the branch growth direction. Distance between two calices within the same row ranges $0.9-1.2 \mathrm{~mm}$.; the nearest calices of two parallel rows were $2-2.7 \mathrm{~mm}$ apart from each other. Up to eight rows of enclosed petaloid septa were found between series of corallites. In most of the corallite, one triplet septa (three septa fusing together) and two duplets (two septa fusing together) reaching fossa were observed. Synapticulothecal wall surrounds calices and rows of enclosed septa were seen in many places of the colony surface. Recorded taxonomic

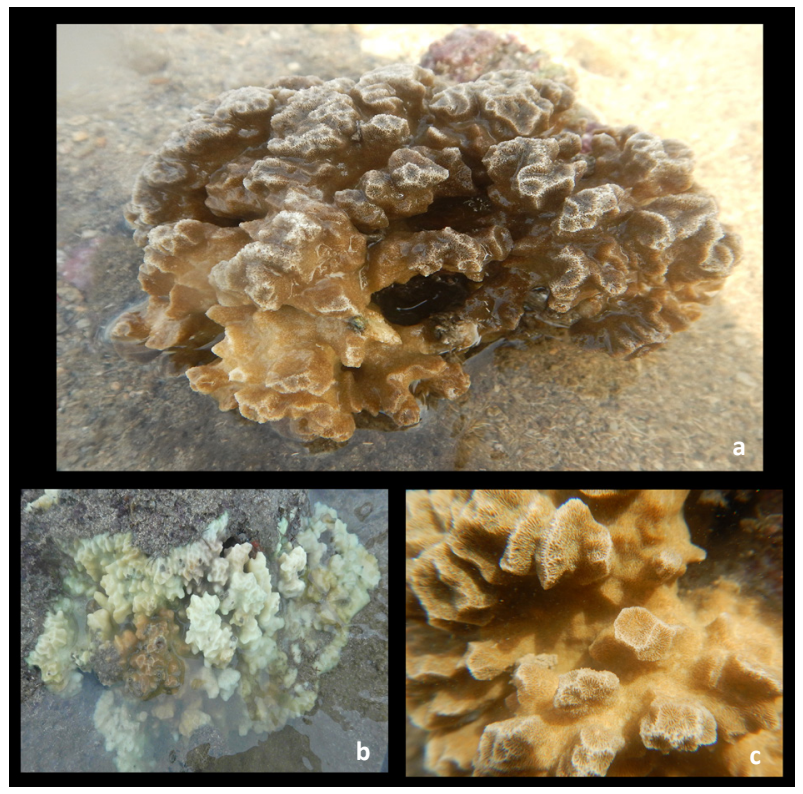

Image 1 . In situ colonies of $\boldsymbol{P}$. contigua: a-ramous | b-encrusting growth forms | c-branch-tips of the colony. (c) Marine National Park, Jamnagar.

characters of the specimen (Table 1) agreed with the description of Psammocora contigua (Esper, 1794).

\section{Discussion}

Psammocora Dana, 1846, is an Indo-Pacific coral genus, presently comprised of 11 nominal species in the monotypic family Psammocoridae (WoRMS 2020). Geographical distribution of the genus extending to 'high latitudes' in both south and north hemispheres, and from the Red Sea and eastern Africa to eastern Pacific shores (Stefani et al. 2008). The Gulf of Kachchh is also located in a marginalized region and proximate to the Red Sea and Arabian Gulf, as their distribution range. Species of this genus have highly plastic branching growth forms and exhibit considerable structural complexity in skeletal features (Benzoni et al. 2007).

All the taxonomical characters of the examined coral colony, in fact, are agreed with the species $P$. obtusangula. The species $P$. obtusangula was considered a valid species by Glynn \& Wellington (1983), Veron (2000), and Reyes-Bonilla (2002). Some studies also claimed it a close synonym of $P$. contigua (Veron \& Pichon 1976; Faure 1982; Scheer \& Pillai 1983) mentioning phenotypic plasticity as the main factor for their morphological variability. But, Stefani et al. (2008) demonstrated the overlapping morphological and molecular characters of $P$. obtusangula and $P$. contigua and synonymized the earlier with later. Hence the Kachchh specimen examined is identified as the species 


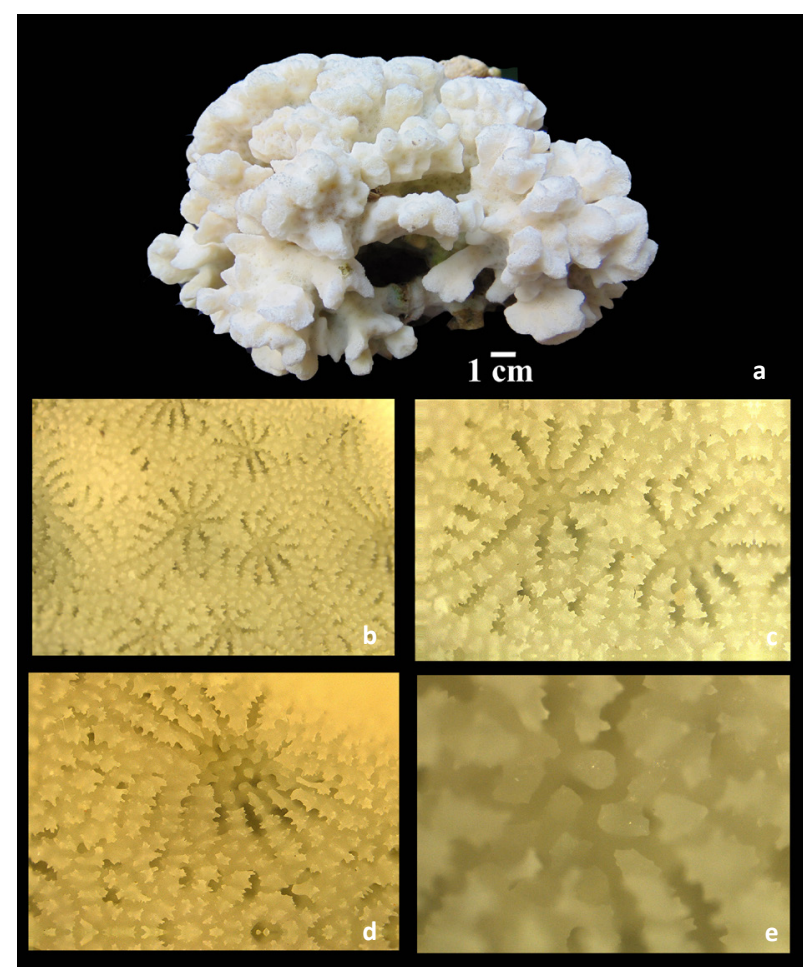

Image 2. a-Examined colony of $P$. contigua | b, c \& d-Corallites arrangement and septal characters | e-Collumella. (c) Marine National Park, Jamnagar

P. contigua. Variation in branching morphology is the main character for considering them as two different species. Branches of $P$. obtusangula are small flattened whereas, in $P$. contigua, the branches are flat and larger. But the variation in branching may be due to the habitats they inhabit. A coral transplantation experiment also suggested that $P$. obtusangula is likely to be a shallow, agitated water form of $P$. contigua only (Hoffmeister 1925). Corals of the Gulf of Kachchh are always a puzzle to taxonomists, as the morphology and growth forms vary due to the existing sedimentation, tidal amplitude, and water current. The same might be the reason for variation in the growth form of the present specimen.

Among the recorded coral species so far from the Kachchh waters, Pocillopora damicornis, Acropora humilis, $A$. squarrosa, $A$. microphthalma are the species having ramose or branching growth forms (Satyanarayana \& Ramakrishna 2009). But all these species are presently considered locally extinct with not even a single live colony recorded since the recent past. So, $P$. contigua is the only living species with somewhat ramose growth form recorded so far from the Kachchh waters.

A total of eight species of corals belonging to the genus Psammocora have been recorded so far from India
Table 1. Recorded morphometrical characters of the examined specimen, $P$. contigua from Gulf of Kachchh.

\begin{tabular}{|c|c|c|}
\hline & $\begin{array}{l}\text { Morphological Characters of Corallites \& } \\
\text { branches }\end{array}$ & $\begin{array}{l}\text { Morphometry } \\
\text { (in } \mathrm{mm} \text { ) }\end{array}$ \\
\hline 1 & Calice diameter & $0.750-0.789$ \\
\hline 2 & Fossa diameter & $0.157-0.184$ \\
\hline 3 & Columella diameter & $0.105-0.131$ \\
\hline 4 & $\begin{array}{l}\text { Maximum width of petaloid septa } \\
\text { Reaching the fossa }\end{array}$ & 0.118 \\
\hline 5 & $\begin{array}{l}\text { Maximum length of petaloid septa } \\
\text { Reaching the fossa }\end{array}$ & 0.302 \\
\hline 6 & Maximum thickness of non-petaloid septa & 0.105 \\
\hline 7 & Maximum width of enclosed petaloid septa & 0.235 \\
\hline 8 & Maximum length of enclosed petaloid septa & 0.392 \\
\hline 9 & Total branch height & Up to 28.92 \\
\hline 10 & Height of the distal portion of the branch & 12.27 \\
\hline 11 & $\begin{array}{l}\text { Minimum distance between the distal } \\
\text { portions of the branch }\end{array}$ & $1.14-2.51$ \\
\hline 12 & $\begin{array}{l}\text { Maximum width of the basal part of the branch } \\
(m-12)\end{array}$ & 23.0 \\
\hline 13 & $\begin{array}{l}\text { Minimum width of the basal part of the branch } \\
\text { perpendicular to } \mathrm{m} 12\end{array}$ & 4.97 \\
\hline 14 & $\begin{array}{l}\text { Maximum width of the distal portion of the } \\
\text { branch }(m-14)\end{array}$ & 46.40 \\
\hline 15 & $\begin{array}{l}\text { Maximum width of the distal portion of the } \\
\text { branch perpendicular to } \mathrm{m} 14\end{array}$ & $19.20-25.0$ \\
\hline 16 & $\begin{array}{l}\text { Minimum width of the distal portion of the } \\
\text { branch perpendicular to } \mathrm{m} 14\end{array}$ & 2.78 \\
\hline
\end{tabular}

Table 2. List of coral species belonging to the genus Psammocora reported so far from Indian waters.

\begin{tabular}{|c|c|c|c|}
\hline & Species & Location of report & Reference \\
\hline \multirow{3}{*}{1} & \multirow{3}{*}{$\begin{array}{l}\text { Psammocora } \\
\text { contigua }\end{array}$} & Lakshadweep & Pillai 1967 \\
\hline & & Gulf of Mannar & Pillai 1986 \\
\hline & & Andaman \& Nicobar & $\begin{array}{l}\text { Venkataraman et al. } \\
2012\end{array}$ \\
\hline \multirow[t]{2}{*}{2} & \multirow[t]{2}{*}{ P. digitata } & Gulf of Kachchh & $\begin{array}{l}\text { Satyanarayana \& } \\
\text { Ramakrishna,2009; } \\
\text { Pillai \& Patel } 1988\end{array}$ \\
\hline & & Lakshadweep & Pillai \& Jasmine 1989 \\
\hline 3 & P. explanulata & Andaman \& Nicobar & $\begin{array}{l}\text { Venkataraman et al. } \\
2012\end{array}$ \\
\hline \multirow[b]{2}{*}{4} & \multirow[b]{2}{*}{ P. haimiana } & Lakshadweep & Pillai 1971 \\
\hline & & Andaman \& Nicobar & $\begin{array}{l}\text { Venkataraman et al. } \\
2012\end{array}$ \\
\hline \multirow[t]{2}{*}{5} & P. nierstraszi & Lakshadweep & Suresh 1991 \\
\hline & P. obtusangula & Andaman \& Nicobar & $\begin{array}{l}\text { Raghuraman et } \\
\text { al.,2012 }\end{array}$ \\
\hline \multirow[b]{2}{*}{6} & \multirow[b]{2}{*}{ P. profundacella } & Lakshadweep & Pillai \& Jasmine 1989 \\
\hline & & Andaman \& Nicobar & $\begin{array}{l}\text { Venkataraman et al. } \\
2012\end{array}$ \\
\hline 7 & P. superficialis & Andaman \& Nicobar & $\begin{array}{l}\text { Venkataraman et al. } \\
2012\end{array}$ \\
\hline 8 & P. vaughani & Andaman \& Nicobar & Mondal et al. 2015 \\
\hline
\end{tabular}


(Table 2). A maximum of seven species were recorded from Andaman \& Nicobar followed by Lakshadweep Islands (five species). P. contigua has been previously reported from the Gulf of Mannar (Pillai 1986), Lakshadweep (Pillai 1967), and Andaman \& Nicobar Island (Venkataraman et al. 2012). But P. obtusangula was only listed out in a checklist of coral species from Andaman \& Nicobar Islands by Raghuraman et al. (2012). Among the recorded 64 coral species so far from Gulf of Kachchh, the genus Psammocora is represented by only one species, P. digitata (Pillai \& Patel 1988; Satyanarayana \& Ramakrishna 2009). The present study adds one more species of corals to the Gulf of Kachchh corals biodiversity. This species distribution was recorded previously from Australia, Indonesia, Singapore, Malaysia, Taiwan, Papua New Guinea, Viet Nam, Thailand, Philippines, Micronesia, Palau, Marshall Islands, Mayotte, Maldives, Japan, New Caledonia, Réunion, Iran, Guam, Yemen, Bahrain, Vanuatu, French Polynesia, Kenya, Ecuador, Kuwait, Seychelles, Fiji, Christmas Island, American Samoa, Pitcairns, Kiribati, USA, and Madagascar (Veron et al. 2016). Veron et al. (2016) also strongly predicted the distribution of $P$. contigua all along the western coast of India, including the Gulf of Kachchh. The present study confirmed their prediction by recording the species in the Gulf of Kachchh.

This species is also classified under 'IUCN Near Threatened' category (IUCN 2020). In the Gulf of Kachchh, the species distribution was rarely encountered at a low-tide exposed reef edge in the eastern side of Narara Island, and their distribution is recorded nowhere else in the Gulf of Kachchh reefs. Even at the recorded reef site also, a small patch of around 8-10 colonies was only observed. A detailed study needs to be carried out along the Kachchh reefs to record their actual distribution. Attempts with the aid of the latest technologies to explore the sub-tidal reefs may yield a greater number of coral species from the isolated reefs of the Gulf of Kachchh.

\section{REFERENCES}

Achituv, Y. \& Z. Dubinsky (1990). Evolution and Zoogeography of Cora Reefs, pp. 1-9. In: Dubinsky, Z. (ed.). Ecosystems of the World, 25 Coral Reefs. Elsevier Science Publishing Company, Inc. Amsterdam, The Netherlands, 550pp.

Benzoni, F., F. Stefani, J. Stolarski, M. Pichon \& P. Galli (2007). Debating phylogenetic relationships of the scleractinian Psammocora: Molecular and morphological evidences. Contributions to Zoology 76(1): 35-54. https://doi.org/10.1163/18759866-07601004

Camp, E.F., V. Schoepf, P.J. Mumby, L.A. Hardtke, R. RodolfoMetalpa, D.J. Smith \& D.J. Suggett (2018). The Future of Coral Reefs Subject to Rapid Climate Change: Lessons from Natural Extreme
Environments. Frontiers in Marine Science 5(4): 1-21. https://doi. org/10.3389/fmars.2018.00004

Cairns, S.D., B.W. Hoeksema \& J. van der Land (1999). Appendix: List of extant stony corals. Atoll Research Bulletin 459: 13-46.

Dixit, A.M., P. Kumar, K.D. Pathak \& M.I. Patel (2010). Economic valuation of coral reef ecosystem in Gulf of Kachchh. Gujarat Ecology Commission, Ghandhinagar, $158 \mathrm{pp}$.

Faure, G.F. (1982). Recherche sur les Peuplements de Scleractiniaires des récifscoralliens de l'Archipel des Mascareignes (OcéanIndien Occidental). PhD Thesis, Universitéd'Aix-Marseille II, 246 pp.

Glynn, P.W. \& G.M. Wellington (1983). Corals and Coral Reefs of the Galapagos Islands. University of California Press, Berkeley/Los Angeles, $330 \mathrm{pp}$.

Hoeksema, B.W. \& S. Cairns (2019). World List of Scleractinia. http:// www.marinespecies.org/scleractinia. Electronic version accessed 20 October 2020.

Hoffmeister, J.E. (1925). Some corals from American Samoa and the Fiji Islands. Papers from the Department of Marine Biology of the Carnegie Institution of Washington 22: 1-90.

Michael, L., D.G. Rao, K.S. Krishna \& K.H. Vora (2009). Late Quaternary seismic sequence stratigraphy of the Gulf of Kachchh, Northwest of India. Journal of Coastal Research 25: 459-468. https://doi. org/10.2112/07-0873.1

Mondal, T., C. Raghunathan \& K. Venkataraman (2015). Report of newly recorded eight scleractinian corals from middle and south Andaman Archipelago, India. Global Journal of Science frontier research C: Biological Science 15(2): 19-26.

Pillai, C.S.G. (1967). Studies on Corals. PhD Thesis, Department of Aquatic Biology \& Fisheries, University of Kerala, XXIV+338 pp.

Pillai C.S.G. (1971). The distribution of shallow water stony corals at Minicoy Atoll in the Indian Ocean with a check-list of species. Atoll Research Bulletin 141: 1-12.

Pillai C.S.G. \& M.I. Patel (1988). Scleractinian Corals from the Gulf of Kutch, Journal of Marine Biological Association of India 30(1\&2): 54-74.

Pillai C.S.G. \& S. Jasmine (1989). The Coral fauna of Lakshadweep. Central Marine Fisheries Research Institute Bulletin 43: 179-195.

Pillai C.S.G. (1986). Recent corals from the southeast of India, pp. 107201. In: James P.S.B.R. (ed.). Recent Advances in Marine Biology. Today and Tomorrow Printers and Publishers, New Delhi, 591 pp.

Raghuraman R., C.R. Sreeraj, C. Raghunathan \& K. Venkataraman (2012). Scleractinian coral diversity in Andaman \& Nicobar Island in comparison with other Indian reefs, pp. 75-92. In: Uttar Pradesh Biodiversity Board (ed.) Marine Biodiversity: One Ocean - Many words of life. Uttar Pradesh State Biodiversity Board, Lucknow, 193 pp.

Reyes-Bonilla, H. (2002). Checklist of valid names and synonyms of stony corals (Anthozoa: Scleractinia) from the eastern Pacific. Journal of Natural History 36: 1-13.

Satyanarayana, C. \& Ramakrishna (2009). Handbook on Hard Corals of Gulf of Kachchh. Published by the Director, Zoological Survey of India, Kolkata, 114 pp.

Satyanarayana, C., T.S.C. Roy, R. Chandran, C. Sivaperuman, C.R. Sreeraj \& K. Chandra (2018). Status of coral resources of India and Strategies for their protection and management, Published by the Director, Zoological Survey of India, Kolkata, 100 pp.

Scheer, G. \& C.S.G. Pillai (1983). Report on the stony corals from the Red Sea. Zoologica 45(3): 1-198.

IUCN (2020). The IUCN Red List of Threatened Species. Version 20202. https://www.iucnredlist.org. Electronic version accessed 22 October 2020.

Srivastava, P.K. (1965). A note on the Quaternary geology of Saurashtra Peninsula. Quaternary Journal of Geology, Minerology and Metallurgical Society of India 1: 55-63.

Spalding, M.D., C. Ravilious, E.P. Green (2001). World atlas of coral reefs. The University of California Press, Berkeley, U.S.A., 424pp.

Stefani. F., F. Benzoni \& M. Pichon (2008). A multidisciplinary approach to the definition of species boundaries in branching species of the coral genus Psammocora (Cnidaria, Scleractinia). Zoologica Scripta 
37: 71-91. https://doi.org/10.1111/j.1463-6409.2007.00309.x

Suresh V.R. (1991). Studies on the coral reefs of Lakshadweep. PhD Thesis. Cochin University of Science and Technology, Kochi, 123 pp. Tenjing, S.Y., P. Krishnan, V.D. Samuel \& R. Purvaja (2019). Truncatoflabellum madrasensissp. nov. - a new ahermatypic coral species from India and a checklist of species of the genus Truncatoflabellum from the Indian Ocean. Vie et milieu - Life and Environment 69(2-3): 89-93.

Venkataraman, K. \& C. Satyanarayana (2012). Coral Identification Manual. Zoological Survey India, Kolkata, 136 pp.

Venkataraman, K., C. Raghunathan, R. Raghuraman, C. Sivaperuman, C.R. Sreeraj, T. Immanuel \& J.S.Y. Kumar (2012). Scleractinia of Andaman and Nicobar Islands. Records of Zoological Survey of India, Zoological Survey India, Kolkata, 304 pp.

Veron, J.E.N. (1995). Corals in space and time: the biogeography and evolution of the Scleractinia. Cornell University Press, Ithaca, London, $321 \mathrm{pp}$

Veron, J.E.N. (2000). Corals of the World. Volumes 1-3. Townsville,
Darwin, Perth: Australian Institute of Marine Science, Townsville, Australia, $1382 \mathrm{pp}$.

Veron J.E.N. \& M. Pichon (1976). Scleractinia of Eastern Australia. I Families Thamnasteriidae, Astrocoeniidae, Pocilloporidae. Australian Institute of Marine Science Monongraph Series 1: 1-86.

Veron, J.E.N., M. Stafford-Smith, L. DeVantier \& E. Turak (2015). Overview of distribution patters of zooxanthellate Scleractinia. Frontiers in Marine Science 1(81): 1-19.

Veron, J.E.N., M.G. Stafford-Smith, E. Turak \& L.M. DeVantier (2016). Corals of the World. http://www.coralsoftheworld.org/species factsheets/species_factsheet_distribution/psammocora-contigua/. Electronic version accessed 22 October 2020.

Wallace, C.C. (1999). Staghorn corals of the world: a revision of the coral genus Acropora (Scleractinia; Astrocoeniina; Acroporidae) worldwide, with emphasis on morphology, phylogeny and biogeography. CSIRO Publishing, Melbourne, Victoria, $422 \mathrm{pp}$.

WoRMS (2020). World Register of Marine Species. Available from http://www.marinespecies.org at VLIZ. Electronic version accessed 17 October 2020 
Dr. John Noyes, Natural History Museum, London, UK

Dr. Albert G. Orr, Griffith University, Nathan, Australia

Dr. Sameer Padhye, Katholieke Universiteit Leuven, Belgium

Dr. Nancy van der Poorten, Toronto, Canada

Dr. Kareen Schnabel, NIWA, Wellington, New Zealand

Dr. R.M. Sharma, (Retd.) Scientist, Zoological Survey of India, Pune, India

Dr. Manju Siliwal, WILD, Coimbatore, Tamil Nadu, India

Dr. G.P. Sinha, Botanical Survey of India, Allahabad, India

Dr. K.A. Subramanian, Zoological Survey of India, New Alipore, Kolkata, India

Dr. P.M. Sureshan, Zoological Survey of India, Kozhikode, Kerala, India

Dr. R. Varatharajan, Manipur University, Imphal, Manipur, India

Dr. Eduard Vives, Museu de Ciències Naturals de Barcelona, Terrassa, Spain

Dr. James Young, Hong Kong Lepidopterists' Society, Hong Kong

Dr. R. Sundararaj, Institute of Wood Science \& Technology, Bengaluru, India

Dr. M. Nithyanandan, Environmental Department, La Ala Al Kuwait Real Estate. Co. K.S.C.,

Kuwait

Dr. Himender Bharti, Punjabi University, Punjab, India

Mr. Purnendu Roy, London, UK

Dr. Saito Motoki, The Butterfly Society of Japan, Tokyo, Japan

Dr. Sanjay Sondhi, TITLI TRUST, Kalpavriksh, Dehradun, India

Dr. Nguyen Thi Phuong Lien, Vietnam Academy of Science and Technology, Hanoi, Vietnam

Dr. Nitin Kulkarni, Tropical Research Institute, Jabalpur, India

Dr. Robin Wen Jiang Ngiam, National Parks Board, Singapore

Dr. Lional Monod, Natural History Museum of Geneva, Genève, Switzerland.

Dr. Asheesh Shivam, Nehru Gram Bharti University, Allahabad, India

Dr. Rosana Moreira da Rocha, Universidade Federal do Paraná, Curitiba, Brasi

Dr. Kurt R. Arnold, North Dakota State University, Saxony, Germany

Dr. James M. Carpenter, American Museum of Natural History, New York, USA

Dr. David M. Claborn, Missouri State University, Springfield, USA

Dr. Kareen Schnabel, Marine Biologist, Wellington, New Zealand

Dr. Amazonas Chagas Júnior, Universidade Federal de Mato Grosso, Cuiabá, Brasil

Mr. Monsoon Jyoti Gogoi, Assam University, Silchar, Assam, India

Dr. Heo Chong Chin, Universiti Teknologi MARA (UiTM), Selangor, Malaysia

Dr. R.J. Shiel, University of Adelaide, SA 5005, Australia

Dr. Siddharth Kulkarni, The George Washington University, Washington, USA

Dr. Priyadarsanan Dharma Rajan, ATREE, Bengaluru, India

Dr. Phil Alderslade, CSIRO Marine And Atmospheric Research, Hobart, Australia

Dr. John E.N. Veron, Coral Reef Research, Townsville, Australia

Dr. Daniel Whitmore, State Museum of Natural History Stuttgart, Rosenstein, Germany.

Dr. Yu-Feng Hsu, National Taiwan Normal University, Taipei City, Taiwan

Dr. Keith V. Wolfe, Antioch, California, USA

Dr. Siddharth Kulkarni, The Hormiga Lab, The George Washington University, Washington,

D.C., USA

Dr. Tomas Ditrich, Faculty of Education, University of South Bohemia in Ceske

Budejovice, Czech Republic

Dr. Mihaly Foldvari, Natural History Museum, University of Oslo, Norway

Dr. V.P. Uniyal, Wildlife Institute of India, Dehradun, Uttarakhand 248001, India

Dr. John T.D. Caleb, Zoological Survey of India, Kolkata, West Bengal, India

Dr. Priyadarsanan Dharma Rajan, Ashoka Trust for Research in Ecology and the Environment

(ATREE), Royal Enclave, Bangalore, Karnataka, India

\section{Fishes}

Dr. Neelesh Dahanukar, IISER, Pune, Maharashtra, India

Dr. Topiltzin Contreras MacBeath, Universidad Autónoma del estado de Morelos, México

Dr. Heok Hee Ng, National University of Singapore, Science Drive, Singapore

Dr. Rajeev Raghavan, St. Albert's College, Kochi, Kerala, India

Dr. Robert D. Sluka, Chiltern Gateway Project, A Rocha UK, Southall, Middlesex, UK

Dr. E. Vivekanandan, Central Marine Fisheries Research Institute, Chennai, India

Dr. Davor Zanella, University of Zagreb, Zagreb, Croatia

Dr. A. Biju Kumar, University of Kerala, Thiruvananthapuram, Kerala, India

Dr. Akhilesh K.V., ICAR-Central Marine Fisheries Research Institute, Mumbai Research

Centre, Mumbai, Maharashtra, India

Dr. J.A. Johnson, Wildlife Institute of India, Dehradun, Uttarakhand, India

Amphibians

Dr. Sushil K. Dutta, Indian Institute of Science, Bengaluru, Karnataka, India

Dr. Annemarie Ohler, Muséum national d'Histoire naturelle, Paris, France

\section{Reptiles}

Dr. Gernot Vogel, Heidelberg, Germany

Dr. Raju Vyas, Vadodara, Gujarat, India

Dr. Pritpal S. Soorae, Environment Agency, Abu Dubai, UAE.

Prof. Dr. Wayne J. Fuller, Near East University, Mersin, Turkey

Prof. Chandrashekher U. Rivonker, Goa University, Taleigao Plateau, Goa. India

Dr. S.R. Ganesh, Chennai Snake Park, Chennai, Tamil Nadu, India

Dr. Himansu Sekhar Das, Terrestrial \& Marine Biodiversity, Abu Dhabi, UAE
Birds

Dr. Hem Sagar Baral, Charles Sturt University, NSW Australia

Dr. Chris Bowden, Royal Society for the Protection of Birds, Sandy, UK

Dr. Priya Davidar, Pondicherry University, Kalapet, Puducherry, India

Dr. J.W. Duckworth, IUCN SSC, Bath, UK

Dr. Rajah Jayapal, SACON, Coimbatore, Tamil Nadu, India

Dr. Rajiv S. Kalsi, M.L.N. College, Yamuna Nagar, Haryana, India

Dr. V. Santharam, Rishi Valley Education Centre, Chittoor Dt., Andhra Pradesh, India

Dr. S. Balachandran, Bombay Natural History Society, Mumbai, India

Mr. J. Praveen, Bengaluru, India

Dr. C. Srinivasulu, Osmania University, Hyderabad, India

Dr. K.S. Gopi Sundar, International Crane Foundation, Baraboo, USA

Dr. Gombobaatar Sundev, Professor of Ornithology, Ulaanbaatar, Mongolia

Prof. Reuven Yosef, International Birding \& Research Centre, Eilat, Israel

Dr. Taej Mundkur, Wetlands International, Wageningen, The Netherlands

Dr. Carol Inskipp, Bishop Auckland Co., Durham, UK

Dr. Tim Inskipp, Bishop Auckland Co, Durham, UK

Dr. V. Gokula, National College, Tiruchirappalli, Tamil Nadu, India

Dr. Arkady Lelej, Russian Academy of Sciences, Vladivostok, Russia

Dr. Simon Dowell, Science Director, Chester Zoo, UK

Dr. Mário Gabriel Santiago dos Santos, Universidade de Trás-os-Montes e Alto Douro,

Quinta de Prados, Vila Real, Portugal

Dr. Grant Connette, Smithsonian Institution, Royal, VA, USA

Dr. M. Zafar-ul Islam, Prince Saud Al Faisal Wildlife Research Center, Taif, Saudi Arabia

Mammals

Dr. Giovanni Amori, CNR - Institute of Ecosystem Studies, Rome, Italy

Dr. Anwaruddin Chowdhury, Guwahati, India

Dr. David Mallon, Zoological Society of London, UK

Dr. Shomita Mukherjee, SACON, Coimbatore, Tamil Nadu, India

Dr. Angie Appel, Wild Cat Network, Germany

Dr. P.O. Nameer, Kerala Agricultural University, Thrissur, Kerala, India

Dr. Ian Redmond, UNEP Convention on Migratory Species, Lansdown, UK

Dr. Heidi S. Riddle, Riddle's Elephant and Wildlife Sanctuary, Arkansas, USA

Dr. Karin Schwartz, George Mason University, Fairfax, Virginia.

Dr. Lala A.K. Singh, Bhubaneswar, Orissa, India

Dr. Mewa Singh, Mysore University, Mysore, India

Dr. Paul Racey, University of Exeter, Devon, UK

Dr. Honnavalli N. Kumara, SACON, Anaikatty P.O., Coimbatore, Tamil Nadu, India

Dr. Nishith Dharaiya, HNG University, Patan, Gujarat, India

Dr. Spartaco Gippoliti, Socio Onorario Società Italiana per la Storia della Fauna "Giuseppe

Altobello", Rome, Italy

Dr. Justus Joshua, Green Future Foundation, Tiruchirapalli, Tamil Nadu, India

Dr. H. Raghuram, The American College, Madurai, Tamil Nadu, India

Dr. Paul Bates, Harison Institute, Kent, UK

Dr. Jim Sanderson, Small Wild Cat Conservation Foundation, Hartford, USA

Dr. Dan Challender, University of Kent, Canterbury, UK

Dr. David Mallon, Manchester Metropolitan University, Derbyshire, UK

Dr. Brian L. Cypher, California State University-Stanislaus, Bakersfield, CA

Dr. S.S. Talmale, Zoological Survey of India, Pune, Maharashtra, India

Prof. Karan Bahadur Shah, Budhanilakantha Municipality, Kathmandu, Nepal

Dr. Susan Cheyne, Borneo Nature Foundation International, Palangkaraja, Indonesia

Dr. Hemanta Kafley, Wildlife Sciences, Tarleton State University, Texas, USA

\section{Other Disciplines}

Dr. Aniruddha Belsare, Columbia MO 65203, USA (Veterinary)

Dr. Mandar S. Paingankar, University of Pune, Pune, Maharashtra, India (Molecular)

Dr. Jack Tordoff, Critical Ecosystem Partnership Fund, Arlington, USA (Communities)

Dr. Ulrike Streicher, University of Oregon, Eugene, USA (Veterinary)

Dr. Hari Balasubramanian, EcoAdvisors, Nova Scotia, Canada (Communities)

Dr. Rayanna Hellem Santos Bezerra, Universidade Federal de Sergipe, São Cristóvão, Brazil

Dr. Jamie R. Wood, Landcare Research, Canterbury, New Zealand

Dr. Wendy Collinson-Jonker, Endangered Wildlife Trust, Gauteng, South Africa

Dr. Rajeshkumar G. Jani, Anand Agricultural University, Anand, Gujarat, India

Dr. O.N. Tiwari, Senior Scientist, ICAR-Indian Agricultural Research Institute (IARI), New

Delhi, India

Dr. L.D. Singla, Guru Angad Dev Veterinary and Animal Sciences University, Ludhiana, India

Dr. Rupika S. Rajakaruna, University of Peradeniya, Peradeniya, Sri Lanka

Dr. Bahar Baviskar, Wild-CER, Nagpur, Maharashtra 440013, India

Reviewers 2018-2020

Due to pausity of space, the list of reviewers for $2018-2020$ is available online.

The opinions expressed by the authors do not reflect the views of the Journal of Threatened Taxa, Wildlife Information Liaison Development Society, Zoo Outreach Organization, or any of the partners. The journal, the publisher, the host, and the partners are not responsible for the accuracy of the political boundaries shown in the maps by the authors.

Journal of Threatened Taxa is indexed/abstracted in Bibliography of Systematic Mycology, Biological Abstracts, BIOSIS Previews, CAB Abstracts, EBSCO, Google Scholar, Index Copernicus, Index Fungorum, JournalSeek, National Academy of Agricultural Sciences, NewJour, OCLC WorldCat, SCOPUS, Stanford University Libraries, Virtual Library of Biology, Zoological Records.

NAAS rating (India) 5.64
Print copies of the Journal are available at cost. Write to:

The Managing Editor, JoTT,

c/o Wildlife Information Liaison Development Society,

No. 12, Thiruvannamalai Nagar, Saravanampatti - Kalapatti Road,

Saravanampatti, Coimbatore, Tamil Nadu 641035, India

ravi@threatenedtaxa.org 


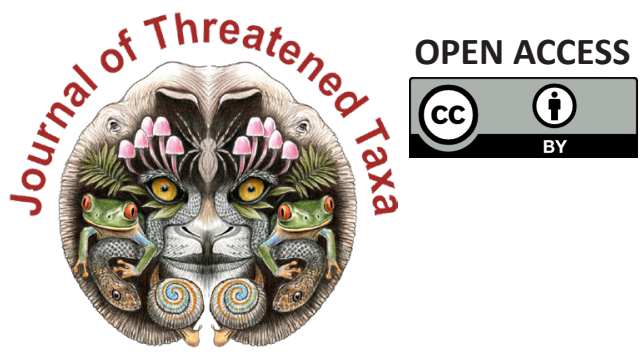

www.threatenedtaxa.org

The Journal of Threatened Taxa (JoTT) is dedicated to building evidence for conservation globally by publishing peer-reviewed articles online every month at a reasonably rapid rate at www.threatenedtaxa.org. All articles published in JoTT are registered under Creative Commons Attribution 4.0 International License unless otherwise mentioned. JoTT allows allows unrestricted use, reproduction, and distribution of articles in any medium by providing adequate credit to the author(s) and the source of publication.

\section{ISSN $0974-7907$ (Online) | ISSN $0974-7893$ (Print)}

\section{December 2021 | Vol. 13 | No. 14 | Pages: 20143-20310 \\ Date of Publication: 26 December 2021 (Online \& Print) DOI: 10.11609/jott.2021.13.14.20143-20310}

\section{Communications}

Updated distribution of seven Trichosanthes L. (Cucurbitales: Cucurbitaceae) taxa in India, along with taxonomic notes

Kanakasabapathi Pradheep, Soyimchiten, Ganjalagatta Dasaiah Harish, Muhammed Abdul Nizar, Kailash Chandra Bhatt, Anjula Pandey \& Sudhir Pal Ahlawat, Pp. 20143-20152

Dragonflies and Damselflies (Insecta: Odonata) of Aryanad Grama Panchayat, Kerala, India

- Reji Chandran \& A. Vivek Chandran, Pp. 20153-20166

Checklist of Odonata (Insecta) of Doon Valley, Uttarakhand, India

- Kritish De, Sarika Bhatt, Amar Paul Singh, Manisha Uniyal \& Virendra Prasad Uniyal, Pp. 20167-20173

Diversity of moths from the urban set-up of Valmiki Nagar, Chennai, India - Vikas Madhav Nagarajan, Rohith Srinivasan \& Mahathi Narayanaswamy, Pp. 20174-20189

Ichthyofaunal diversity with relation to environmental variables in the snowfed Tamor River of eastern Nepal

- Jawan Tumbahangfe, Jash Hang Limbu, Archana Prasad, Bhrarat Raj Subba \& Dil Kumar Limbu, Pp. 20190-20200

Observations on the foraging behavior of Tricoloured Munia Lonchura malacca (Linnaeus, 1766) and its interaction with pearl millet fields in Villupuram District, Tamil Nadu, India

- M. Pandian, Pp. 20201-20208

Roosting patterns of House Sparrow Passer domesticus Linn., 1758 (Aves: Passeridae) in Bhavnagar, Gujarat, India

- Foram P. Patel \& Pravinsang P. Dodia, Pp. 20209-20217

Review

Comprehensive checklist of algal class Chlorophyceae (sensu Fritsch, 1935) for Uttar Pradesh, India, with updated taxonomic status

- Sushma Verma, Kiran Toppo \& Sanjeeva Nayaka, Pp. 20218-20248

\section{View Point}

Wildlife managers ignore previous knowledge at great risk: the case of Rivaldo, the iconic wild Asian Elephant Elephas maximus L. of the Sigur Region, Nilgiri Biosphere Reserve, India

- Jean-Philippe Puyravaud \& Priya Davidar, Pp. 20249-20252

\section{Short Communications}

Diversity and distribution of macro lichens from Kalpetta Municipality of Wayanad District, Kerala, India

- Greeshma Balu, A.R. Rasmi, Stephen Sequeira \& Biju Haridas, Pp. 20253-20257

Extended distribution of two endemic epiphytes from the Western Ghats to the Deccan Plateau

- Sonali Vishnu Deore, Mangala Dala Sonawane \& Sharad Suresh Kambale, Pp. 20258-20260

Nomenclatural notes and report of Boehmeria penduliflora Wedd. ex D.G. Long from the Terai region of Uttar Pradesh, India

- Amit Gupta, Imtiyaz Ahmad Hurrah, Aparna Shukla \& Vijay V. Wagh, Pp. 2026120265
New distribution record of a true coral species, Psammocora contigua (Esper, 1794) from Gulf of Kachchh Marine National Park \& Sanctuary, India - R. Chandran, R. Senthil Kumaran, D.T. Vasavada, N.N. Joshi \& Osman G. Husen, Pp. 20266-20271

A new species of flat-headed mayfly Afronurus meenmutti (Ephemeroptera: Heptageniidae: Ecdyonurinae) from Kerala, India

- Marimuthu Muthukatturaja \& Chellaiah Balasubramanian, Pp. 20272-20277

Photographic record of Dholes predating on a young Banteng in southwestern Java, Indonesia

- Dede Aulia Rahman, Mochamad Syamsudin, Asep Yayus Firdaus, Herry Trisna Afriandi \& Anggodo, Pp. 20278-20283

Latrine site and its use pattern by Large Indian Civet Viverra zibetha Linnaeus, 1758: record from camera trap

- Bhuwan Singh Bist, Prashant Ghimire, Basant Sharma, Chiranjeevi Khanal \& Anoj Subedi, Pp. 20284-20287

Notes

Two additions to the flora of Kerala, India

- P. Murugan, Basil Paul \& M. Sulaiman, Pp. 20288-20291

Pentatropis R.Br. ex Wight \& Arn. (Apocynaceae), a new generic record for Kerala, India

- V. Ambika, Jose Sojan \& V. Suresh, Pp. 20292-20294

New record of Kashmir Birch Mouse Sicista concolor leathemi (Thomas, 1893) (Rodentia: Sminthidae) in the Indian Himalaya

- S.S. Talmale, Avtar Kaur Sidhu \& Uttam Saikia, Pp. 20295-20298

Breeding record of Black-headed Ibis Threskiornis melanocephalus (Aves: Threskiornithidae) at Mavoor wetland, Kozhikode District, Kerala, India - C.T. Shifa, Pp. 20299-20301

\section{Response}

Crop and property damage caused by Purple-faced Langurs Trachypithecus vetulus (Mammalia: Primates: Cercopithecidae) - Vincent Nijman, Pp. 20302-20306

Reply

If habitat heterogeneity is effective for conservation of butterflies in urban landscapes of Delhi, India? Unethical publication based on data manipulation: Response of original authors

- Monalisa Paul \& Aisha Sultana, Pp. 20307-20308

\section{Book Review}

Freshwater fishes of the Arabian Peninsula - Rajeev Raghavan, Pp. 20309-20310

Publisher \& Host

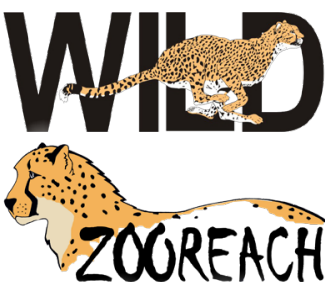

Threatened Taxa 